\title{
TATA KELOLA DAN FAKTOR LAIN YANG MEMPENGARUHI PENGUNGKAPAN TANGGUNG JAWAB SOSIAL PERUSAHAAN PADA PERUSAHAAN MANUFAKTUR
}

\author{
CINDY NATASHYA \\ ASTRID RUDYANTO \\ Trisakti School of Management, Jl. Kyai Tapa No. 20, Jakarta, Indonesia \\ natashyacindy98@gmail.com
}

\begin{abstract}
This study aims to examine the effect of corporate governance (board size, board independence, women on board, internationalization) and other firm characteristics (firm size, profitability, financial leverage, and listing age) on corporate social responsibility disclosure. This research used 132 manufacturing companies listed in Indonesia Stock Exchange during years 2015-2018. Samples were selected by purposive sampling method. Data analysis was performed with SPSS 19th Version Program. Multiple regression was used to analyze data. The result shows that board size, firm size, profitability, and listing age have influence on corporate social responsibility disclosure. While board independence, women on board, financial leverage, and internationalization have no effect on corporate social responsibility disclosure.
\end{abstract}

Keywords: Corporate social responsibility disclosure, board characteristics, firm characteristics, manufacturing companies

\begin{abstract}
Abstrak: Penelitian bertujuan untuk menguji pengaruh tata kelola perusahaan (board size, board independence, women on board, internationalization) dan karakteristik perusahaan lainnya (firm size, profitability, financial leverage, and listing age) terhadap pengungkapan tanggung jawab sosial perusahaan. Sample yang digunakan adalah 132 data perusahaan manufaktur yang terdapat di Bursa Efek Indonesia selama tahun 2015-2018. Metode pengambilan sampel menggunakan metode purposive sampling. Pengolahan data menggunakan SPSS versi 19. Analisis regresi berganda digunakan untuk menganalisis data. Hasil penelitian menunjukkan bahwa variabel board size, profitability, firm size, dan listing age memiliki pengaruh terhadap pengungkapan tanggung jawab sosial perusahaan. Sedangkan board independence, women on board, financial leverage, dan internationalization tidak memiliki pengaruh terhadap pengungkapan tanggung jawab sosial perusahaan.
\end{abstract}

Kata kunci: Pengungkapan tanggung jawab sosial perusahaan, karakteristik dewan, karakteristik perusahaan, perusahaan manufaktur

\section{PENDAHULUAN}

$\begin{array}{lr}\text { Keberlangsungan } & \text { sebuah } \\ \text { perusahaan akan terjamin apabila } \\ \text { perusahaan memperhatikan kondisi sosial } \\ \text { dan lingkungannya. Masyarakat disekitar }\end{array}$

tempat usaha juga harus mengetahui informasi terkait aktivitas perusahaan sehingga masyarakat tahu bagaimana kontribusi perusahaan terhadap masyarakat sekitar. Adanya perubahan masyarakat yang semakin kritis di era sekarang ini 
memunculkan kesadaran perusahaan tentang pentingnya melakukan tanggung jawab sosial perusahaan atau yang sering disebut dengan tanggung jawab sosial perusahaan (CSR) (Almilia et al. 2011).

Salah satu kasus yang berkaitan dengan tanggung jawab sosial perusahaan adalah kasus PT. Rayon Utama Makmur, dimana perusahaan ini memproduksi serat kain sintesis yang menyebabkan pencemaran udara dilingkungan sekitar perusahaan. Munculnya bau tidak sedap mengakibatkan gangguan kesehatan pada warga sekitar lokasi perusahaan dengan gejala mual, pusing, dan muntah. Menanggapi kasus ini, KPAl berkoordinasi dengan Bupati Kabupaten Sukoharjo dan dinas terkait seperti dinas lingkungan hidup, dinas pendidikan, dinas pemberdayaan perempuan dan perlindungan anak serta kepolisian setempat untuk melakukan pengawasan di sekitar lokasi perusahaan (Tirto 2018). Akibatnya kepercayaan masyarakat terhadap PT. Rayon Utama Makmur berkurang.

Kasus di atas menunjukkan bahwa tanggung jawab sosial perusahaan sangat penting bagi image perusahaan. Karena itu, untuk menunjukkan pada masyarakat bahwa perusahaan melakukan tanggung jawab sosial dan tidak merugikan masyarakat seperti kasus di atas, perusahaan perlu mengungkapkan tanggung jawab sosial perusahaan. Pemerintah menetapkan Undang-Undang (UU) No. 40 Tahun 2007 tentang Perseroan Terbatas dalam pasal 74 yang menyatakan bahwa Perseroan wajib melaksanakan tanggung jawab sosial dan lingkungan (Agustia 2013). serta mengungkapkannya baik dalam laporan keuangan maupun laporan terpisah. Namun peraturan ini tidak mengatur apa saja yang perlu diungkapkan dalam laporan tersebut serta sejauh mana tanggung jawab sosial harus diungkapkan. Karena itu, pengungkapan tanggung jawab sosial perusahaan tergantung pada tata kelola perusahaan dan karakteristik perusahaan lainnya.

Tujuan dilakukannya penelitian ini adalah untuk menganalisa pengaruh tata kelola perusahaan (board size, board independence, women on board, internationalization) dan karakteristik perusahaan lainnya (firm size, profitability, dan listing age) terhadap pengungkapan tanggung jawab sosial perusahaan. penelitian ini dengan penelitian sebelumnya terletak pada variabel yang diuji. Penelitian ini mengacu penelitian yang dilakukan oleh Isa dan Muhammad (2015). Penelitian ini menambahkan beberapa variabel lain yaitu profitability, financial leverage, internationalization, dan listing age. Penelitian ini juga menggunakan perusahaan non keuangan untuk menambah generalisasi penelitian sebelumnya. Perusahaan keuangan tidak dijadikan sampel karena perusahaan keuangan diawasi oleh Otoritas Jasa Keuangan sehingga ada kemungkinan luasnya pengungkapan tanggung jawab sosial perusahaan pada perusahaan tersebut bukan karena tata kelola perusahaan dan karakteristik perusahaan, tapi karena pengawasan Otoritas Jasa Keuangan (Rudyanto 2019).

\section{Teori Agensi}

Teori ini melibatkan pelimpahan wewenang principal sebagai pemilik perusahaan kepada agen sebagai pihak yang mengelola perusahaan dalam pengambilan keputusan (Jensen dan Meckling, 1976). Manajer tidak selamanya melakukan tindakan yang sesuai dengan yang diharapkan pemilik perusahaan, manajer sering melakukan tindakan yang hanya menguntungkan dirinya sendiri (Ramadhaningsih dan Utama, 2013). Oleh karena ini, teori agensi menggambarkan semua individu bertindak atas kepentingan diri 
masing-masing (Bangun et al. 2016). Adanya pemisahan tugas antara principal dan agent menyebabkan munculnya konflik keagenan. Konflik keagenan muncul karena adanya asimetri informasi antara manajer dan pemegang saham. Salah satu cara untuk mengurangi asimetri informasi adalah dengan melakukan pengungkapan tanggung jawab sosial perusahaan.

\section{Teori Legitimasi}

Teori legitimasi penting dalam menjelaskan bagaimana perilaku organisasi dalam menerapkan dan mengembangkan tanggung jawab sosial serta mengkomunikasikan hasilnya kepada masyakarat sekitar perusahaan. Konsep legitimasi menunjukkan adanya kontrak sosial yang secara implisit perusahaan bertanggung jawab pada tuntutan masyakarat. Perusahaan perlu memahami bahwa keberlangsungan perusahaan berkaitan dengan citra perusahaan dengan masyarakat sekitar perusahaan tersebut (Agustia 2013). Aktivitas dan keberadaan perusahaan harus terlegitimasi dalam mata masyarakat (Yuliana et al. 2008). Untuk mencapai legitimasi, perusahaan melakukan pengungkapan untuk mendemonstrasikan perhatian manajemen dalam bidang sosial (Rokhlinasari 2015).

\section{Tata Kelola Perusahaan}

Tata kelola perusahaan merupakan suatu sistem yang mengatur dan mengontrol suatu perusahaan (Rasyidah 2013). Terdapat dua sistem tata kelola perusahaan yaitu one-tier board dan two-tier board. Berdasarkan UndangUndang No. 40 Tahun 2007 tentang Perseroan Terbatas, Indonesia menggunakan sistem twotier dimana adanya pemisahan wewenang pengurusan dan pengawasan perusahaan yang dikenal dengan direksi dan dewan komisaris. Variabel yang berkaitan dengan tata kelola perusahaan adalah board size sebagai pihak yang melakukan mengawasi pengelolaan perusahaan, board independence sebagai pihak yang mengawasi manajemen, serta internationalization sebagai pihak asing yang mempertahankan legitimasi perusahaan dimata masyarakat. Salah satu prinsip corporate governance adalah transparansi dimana perusahaan dituntut untuk memberikan informasi yang transparan. Perusahaan berusaha meyakinkan investor bahwa mereka sepenuhnya transparan serta berkomitmen untuk tata kelola perusahaan yang jujur dan adil (Gill 2008). Hal ini menunjukkan semakin baik tata kelola perusahaannya semakin memaksa perusahaan untuk menungkapkan aktivitas sosialnya yaitu tanggung jawab sosial perusahaan (Anggraini 2006).

\section{Board size terhadap Pengungkapan Tanggung Jawab Sosial Perusahaan}

Dewan komisaris adalah wakil shareholder dalam Perseroan Terbatas (PT) yang berfungsi untuk mengawasi pengelolaan perusahaan oleh manajer maupun direksi dan bertanggung jawab dalam pemenuhan tanggung jawab manajemen terkait pengelolaan dan penyelenggaraan pengendalian internal perusahaan (Nur dan Priantinah 2012). Semakin besar ukuran dewan komisaris, maka pengendalian dan pengawasannya akan semakin mudah dan efektif (Coller dan Gregory 1999). Dapat disimpulkan bahwa semakin besar ukuran dewan komisaris maka semakin besar pula pengungkapan tanggung jawab sosial perusahaannya (Japoetra \& Susanto 2020, Susanto 2019).

$\mathrm{H}_{1}$ : Board size memiliki pengaruh terhadap pengungkapan tanggung jawab sosial perusahaan

\section{Board independence terhadap Pengungkapan Tanggung Jawab Sosial Perusahaan}

Board independence mengacu pada jumlah direksi non-eksekutif yang duduk dalam dewan (Isa dan Muhammad 2015). Kepentingan 
manajer dan pemegang saham dapat diselaraskan oleh adanya dewan komisaris, karena mereka mewakili mekanisme internal utama untuk mengawasi perilaku yang mengeksploitasi peluang atau keuntungan jangka pendek dan mengabaikan keuntungan jangka panjang manajemen, hal ini dapat dilihat dari perspektif teori agensi (Badjuri 2011). Kehadiran direktur independen dalam dewan akan meningkatkan tanggung jawab sosial perusahaan (Susanto \& Joshua 2018, Jo dan Harjoto 2011).

$\mathrm{H}_{2}$ : Board independence memiliki pengaruh terhadap tanggung jawab sosial perusahaan

\section{Women on Board terhadap pengungkapan tanggung jawab sosial perusahaan}

Dalam menanggapi masalah tanggung jawab sosial perusahaan direktur wanita dianggap lebih serius karena orientasi moral serta reputasi direktur wanita lebih kuat dibandingkan direktur pria (Hyun et al. 2016). Anggota dewan wanita cenderung menunjukkan simpati terhadap tanggung jawab sosial perusahaan yang termasuk berpartisipasi terhadap acara sosial masyarakat. Dan perusahaan yang memiliki anggota dewan wanita akan memberikan partisipasi lebih banyak dalam upaya pengungkapan tanggung jawab sosial perusahaan (Bernardi et al. 2009). Hal ini menunjukkan bahwa semakin besar jumlah wanita yang duduk dalam dewan akan meningkatkan kesejahteraan masyarakat disekitar perusahaan melalui pengungkapan tanggung jawab sosialnya

$\mathrm{H}_{3}$ : Women on Board memiliki pengaruh terhadap Pengungkapan tanggung jawab sosial perusahaan

\section{Internationalization terhadap pengungkapan tanggung jawab sosial perusahaan}

Internasionalisasi

membuat perusahaan mengungkapkan informasi lebih banyak karena menghadapi pasar yang lebih bervariasi (Kolk dan Fortanier 2013).
Perusahaan yang lebih beragam di pasar geograsi mempunyai pemangku kepentingan yang lebih bervariasi (Dyduch dan Krasodomska 2017). Efek dari pengungkapan tanggung jawab sosial adalah meningkatkan reputasi perusahaan serta pengurangan risiko dan biaya (Folk dan Fortainer 2013 dalam Dyduch dan Krasodomska 2017). Jika dikaitkan dengan teori legitimasi, internasionalisasi mendorong perusahaan untuk mempertahankan citranya dimata masyarakat dan mencegah rusaknya citra perusahaan.

$\mathrm{H}_{4}$ : Internationalization memiliki pengaruh terhadap Pengungkapan tanggung jawab sosial perusahaan

\section{Firm size terhadap Pengungkapan tanggung jawab sosial perusahaan}

Skala ukuran

mempengaruhi luasnya pengungkapan informasi dalam laporan keuangan. Perusahaan besar biasanya mempunyai aktivitas yang lebih banyak dan kompleks, berdampak besar bagi masyakarat, memiliki shareholders yang lebih banyak serta mendapat perhatian lebih dari publik (Dermawan dan Deitiana 2014). Informasi yang tersedia di perusahaan besar akan lebih banyak dan mudah diakses oleh publik jika dibandingkan dengan informasi yang tersedia di perusahaan kecil (Dewi dan Keni 2013).

$\mathrm{H}_{5}$ : Firm size memiliki pengaruh terhadap tanggung jawab sosial perusahaan

\section{Profitability terhadap pengungkapan tanggung jawab sosial perusahaan}

Profitability merupakan rasio untuk menilai kemampuan perusahaan dalam menghasilkan keuntungan (Prihadi, 2008). Kondisi keuangan yang kuat akan berdampak pada tekanan dari pihak eksternal perusahaan sehingga perusahaan memiliki kewajiban untuk mengungkapkan tanggung jawab sosial perusahaan secara lebih luas (Dermawan dan Deitiana 2014). 
$\mathrm{H}_{6}$ : Profitability memiliki pengaruh terhadap Pengungkapan tanggung jawab sosial perusahaan

\section{Financial leverage terhadap pengungkapan} tanggung jawab sosial perusahaan

Financial leverage menjadi faktor peningkatan pengembalian yang diharapkan perusahaan dengan risiko biaya yang tinggi (Higgins 2016). Perusahaan dengan tingkat leverage yang tinggi memiliki kewajiban lebih untuk memberikan informasi kepada krediturnya termasuk informasi tanggung jawab sosial perusahaan (Santioso dan Chandra 2012). Hal ini dilakukan guna menghilangkan keraguan kreditor terhadap dipenuhinya hak-hak kreditor (Dewi dan Keni 2013).

$\mathrm{H}_{7}$ : Financial leverage memiliki pengaruh terhadap Pengungkapan tanggung jawab sosial perusahaan

\section{Listing age terhadap Pengungkapan tanggung jawab sosial perusahaan}

Lamanya perusahaan terdaftar sebagai perusahaan go-public mempengaruhi tingkat pengungkapan tanggung jawab sosial perusahaan pada laporan keuangan perusahaan (Sufian 2012). Umur perusahaan menjadi faktor yang mempengaruhi pengungkapan tanggung jawab sosial perusahaan melalui kemampuan perusahaan mengatasi hambatan yang mengancam keberlangsungan perusahaan. Perusahaan yang lebih berumur tua lebih paham mengenai apa saja yang sebaiknya diungkapkan dalam laporan tahunan karena banyaknya pengalaman yang sudah dilewati (Nugrahanti 2013). Hal ini menunjukkan bahwa Semakin lama perusahaan berdiri maka perusahaan akan mengetahui kebutuhan investor tentang perusahaan termasuk informasi mengenai pengungkapan tanggung jawab sosial perusahaan (Untari 2010).

$\mathrm{H}_{8}$ : Listing age memiliki pengaruh terhadap Pengungkapan tanggung jawab sosial perusahaan

\section{METODA}

Populasi yang terdapat dalam penelitian ini adalah perusahaan manufaktur yang terdaftar di Bursa Efek Indonesia selama tahun 2015 hingga tahun 2018 sebanyak 65 perusahaan (132 data) yang dilakukan dengan metode purposive sampling. Berikut ini adalah hasil pemilihan sampel.

Tabel 1 Prosedur Pemilihan Sample

\begin{tabular}{ccc}
\hline Kriteria & Perusahaan & Data \\
\hline $\begin{array}{c}\text { Perusahaan manufaktur yang terdaftar di Bursa } \\
\text { Efek Indonesia periode 2015 - 2018 secara } \\
\text { konsisten. }\end{array}$ & 132 & 528 \\
$\begin{array}{c}\text { Perusahaan manufaktur yang laporan keuangan } \\
\text { yang tidak berakhir pada tanggal 31 } \\
\quad \text { Desember. }\end{array}$ & $(1)$ & $(4)$ \\
$\begin{array}{c}\text { Perusahaan manufaktur yang tidak menggunakan } \\
\text { mata uang rupiah dalam laporan keuangannya. } \\
\text { Perusahaan yang tidak memperoleh laba selama } \\
\text { periode 2015 - 2017 secara konsisten. }\end{array}$ & $(28)$ & $(112)$ \\
\hline Sampel yang digunakan & 65 & $\mathbf{2 6 0}$ \\
\hline
\end{tabular}


Pengungkapan tanggung jawab sosial perusahaan diukur dengan analisis isi terhadap item-item pengungkapan (Sembiring 2005). Apabila terdapat item pengungkapan dalam laporan tahunan, maka akan diberikan nilai 1. Dan jika tidak terdapat item pengungkapan dalam laporan tahunan tersebut, maka diberikan nilai 0 . Hasilnya akan dibagi dengan 78 pengungkapan sehingga menghasilkan Pengungkapan tanggung jawab sosial perusahaan index.

Board size adalah direktur yang duduk dalam dewan komisaris. Dalam penelitian ini, board size diukur dengan jumlah dewan komisaris dalam dewan direksi perusahaan. Skala yang digunakan dalam mengukur variabel board size adalah skala rasio, dimana hal ini konsisten dengan yang digunakan oleh Isa dan Muhammad (2015).

Board independence adalah komisaris independent (Isa dan Muhammad 2015).Dalam penelitian ini, board independence diukur dengan skala rasio yang konsisten dengan yang dilakukan oleh Isa dan Muhammad (2015) yaitu jumlah komisaris independen dibagi total komisaris.

Women on board adalah wanita yang duduk dalam dewan direksi (Isa dan Muhammad 2015). Variabel ini diukur dengan jumlah dewan wanita yang duduk dalam dewan direksi perusahaan.

Internasionalisasi dalam bidang ekonomi diartikan sebagai sebuah proses peningkatan keterlibatan perusahaan dalam pasar internasional (Dyduch dan Krasodomska 2017). Variabel internationalization diukur berdasarkan pada jumlah direksi asing yang terdapat dalam perusahaan. Pengukuran variabel internationalization menggunakan skala rasio sesuai dengan penelitian yang dilakukan oleh Dyduch dan Krasodomska (2017).

Firm size adalah ukuran perusahaan. Besar kecilnya perusahaan dapat diukur dari nilai total asset perusahaan. Pada penelitian ini, variabel firm size diukur menggunakan skala rasio menggunakan logaritma natural dari seluruh total asset yang dimiliki perusahaan (Isa dan Muhammad 2015).

Profitability menggambarkan kinerja dari sebuah perusahaan. Kinerja perusahaan ditunjukkan dengan kemampuan perusahaan dalam menghasilkan laba dari kegiatan operasionalnya sehari-hari (Santioso dan Chandra 2012). Dalam penelitian ini, tingkat profitabilitas akan diukur menggunakan Return on Sales (ROS). Pengukuran variable ini konsisten dengan penelitian yang dilakukan oleh Dyduch dan Krasodomska (2017).

Financial leverage menggambarkan struktur keuangan perusahaan serta dapat mengukur risiko jangka panjang yang disebabkan oleh struktur tersebut. Financial leverage yang tinggi menunjukkan risiko kegagalan perusahaan yang tinggi pula. Dalam penelitian ini, variabel financial leverage diukur menggunakan Debt to Total Assets Ratio yang konsisten digunakan oleh Dyduch dan Krasodomska (2017).

Listing age adalah usia sebuah perusahaan terdaftar dalam pasar modal. Variabel listing age diukur berdasarkan lamanya sebuah perusahaan terdaftar di Bursa Efek Indonesia (BEI). Pengukuran variabel ini menggunakan skala rasio yang konsisten dengan penelitian yang dilakukan oleh Uyar et al. (2013).

\section{HASIL DAN PEMBAHASAN}

Hasil perhitungan statistik deskriptif ditampilkan pada tabel 2 dan 3 sedangkan hasil uji $\mathrm{t}$ ditampilkan pada tabel 4. Berdasarkan pengujian statistik deskriptif terhadap pengungkapan tanggung jawab sosial perusahaan, pengungkapan dalam segmen lingkungan yang paling besar berada pada tahun 2017 dengan nilai rata-rata sebesar 0.31. Pengungkapan dalam segmen energi paling 
besar berada pada tahun 2018 dengan nilai ratarata sebesar 0.21 . Untuk segmen tenaga kerja paling besar berada pada tahun 2018 dengan nilai rata-rata sebesar 0.25 . Sementara itu, pengungkapan dalam segmen produk paling besar berada pada tahun 2018 dengan nilai ratarata sebesar 0.26 . Sedangkan pengungkapan dalam segmen keterlibatan masyarakat paling besar berada pada tahun 2016 dengan nilai ratarata 0.27 .

Tabel 2 Statistik Deskriptif

\begin{tabular}{cccccc}
\hline Varaibel & $\mathbf{N}$ & Minimum & Maksimum & Rata-rata & Standar deviasi \\
\hline CSRD & 260 & 0.00 & 0.54 & 0.26 & 0.11 \\
BS & 260 & 2 & 13 & 4.3 & 1.9 \\
BI & 260 & 0.20 & 0.80 & 0.40 & 0.10 \\
WOB & 260 & 0 & 3 & 0.45 & 0.74 \\
INTER & 260 & 0 & 9 & 1.01 & 1.77 \\
SIZE & 260 & 24.61 & 33.19 & 28.51 & 1.53 \\
PROF & 260 & 0.01 & 0.53 & 0.12 & 0.08 \\
LEV & 260 & 0.07 & 0.81 & 0.38 & 0.17 \\
AGE & 260 & 1 & 38 & 20.90 & 9.55 \\
\hline
\end{tabular}

Sumber: Hasil pengolahan data SPSS

Tabel 3 Statistik Deskriptif CSRD

\begin{tabular}{ccccc}
\hline Item & $\mathbf{2 0 1 5}$ & $\mathbf{2 0 1 6}$ & $\mathbf{2 0 1 7}$ & $\mathbf{2 0 1 8}$ \\
\hline LINGKUNGAN & 0,27 & 0,29 & 0,31 & 0,29 \\
ENERGI & 0,17 & 0,18 & 0,18 & 0,21 \\
TENAGA KERJA & 0,22 & 0,23 & 0,23 & 0,25 \\
$\begin{array}{c}\text { PRODUK } \\
\text { KETERLIBATAN } \\
\text { MASYARAKAT }\end{array}$ & 0,25 & 0,25 & 0,25 & 0,26 \\
UMUMM & 0,25 & 0,27 & 0,26 & 0,26 \\
\hline
\end{tabular}

Sumber: Hasil pengolahan data SPSS 
Tabel 4 Uji t dan Uji F

\begin{tabular}{ccc}
\hline Model & \multicolumn{1}{c}{ B } & Sig. \\
\hline BS &, 026 &, 000 \\
BI &,- 094 &, 101 \\
WOB &,- 011 &, 170 \\
INTER &, 004 &, 153 \\
F.SIZE &, 013 &, 002 \\
PROFIT &, 282 &, 000 \\
LEV &, 029 &, 392 \\
AGE &,- 002 &, 001 \\
Adjusted R2 &, 383 & \\
F & 21,131 &, 000 \\
\hline
\end{tabular}

Sumber: Hasil pengolahan data SPSS

Variabel board size memiliki nilai signifikansi sebesar 0.000 dimana nilai tersebut lebih kecil dari 0.05 sehingga $\mathrm{H}_{1}$ diterima, artinya board size memiliki pengaruh terhadap pengungkapan tanggung jawab sosial perusahaan dan arahnya positif. Semakin besar ukuran dewan komisaris, semakin besar pula pengaruh yang diberikan. Komisaris mampu menekan manajemen untuk memberikan kontribusi terhadap pengungkapan CSR (Wagiu dan Mekel 2014).

Variabel board independence memiliki nilai signifikansi sebesar 0.101 dimana nilai tersebut lebih besar dari 0.05 sehingga $\mathrm{H}_{2}$ tidak diterima, artinya board independence tidak memiliki pengaruh terhadap pengungkapan tanggung jawab sosial perusahaan dan arahnya positif. Tidak semua dewan komisaris independen dapat menunjukkan independensinya sehingga pengawasan tidak berjalan dengan baik yang mengakibatkan kurangnya dorongan kepada manajemen untuk melakukan pengungkapan sosial perusahaan (Chintya 2012).

Variabel women on board memiliki nilai signifikansi sebesar 0.170 dimana nilai tersebut lebih besar dari 0.05 sehingga $\mathrm{H}_{3}$ tidak diterima, artinya women on board tidak memiliki pengaruh terhadap pengungkapan tanggung jawab sosial perusahaan dan arahnya negatif. Perempuan cenderung menghindari risiko yang menyebabkan sikap kehati-hatian dalam bersikap maupun bertindak yang pada akhirnya mempengaruhi pengambilan keputusan. Selain itu, minoritas kaum perempuan dalam sebuah perusahaan mengakibatkan kecilnya pengaruh komisaris perempuan dalam menentukan keputusan (Pajaria et al. 2016).

Variabel internationalization memiliki nilai signifikansi sebesar 0.153 dimana nilai tersebut lebih besar dari 0.05 sehingga $\mathrm{H}_{4}$ tidak diterima, artinya internationalization tidak memiliki pengaruh terhadap pengungkapan tanggung jawab sosial perusahaan dan arahnya positif. Rata-rata sample dalam penelitian ini adalah perusahaan yang tidak memiliki manajemen asing namun pengungkapan CSR sudah cukup efektif terlaksana (Rohmah 2015). Alasan lain mengenai tidak terdapat pengaruh manajemen asing terhadap pengungkapan CSR karena kemungkinan manajemen asing dalam perusahaan di Indonesia secara umum belum mempedulikan masalah lingkungan dan sosial sebagai suatu hal yang harus diungkapkan dalam laporan tahunan (Rohmah 2015). Dengan demikian, besar kecilnya jumlah direksi asing dalam perusahaan tidak mempengaruhi pengungkapan CSR yang dilakukan perusahaan. 
Variabel firm size memiliki nilai signifikansi sebesar 0.002 dimana nilai tersebut lebih kecil dari 0.05 sehingga $\mathrm{H}_{5}$ diterima, artinya firm size memiliki pengaruh terhadap pengungkapan tanggung jawab sosial perusahaan dan arahnya positif. Perusahaan besar biasanya memiliki aktivitas yang lebih banyak, berdampak besar bagi perusahaan, dan mendapat perhatian lebih dari masyarakat sehingga meningkatkan pengungkapan tanggung jawab sosial perusahaan (Dermawan dan Deitiana 2014).

Variabel profitability memiliki nilai signifikansi sebesar 0.000 dimana nilai tersebut lebih kecil dari 0.05 sehingga $\mathrm{H}_{6}$ diterima, artinya profitability memiliki pengaruh terhadap pengungkapan tanggung jawab sosial perusahaan dan arahnya positif. Kondisi keuangan yang kuat akan berdampak pada tekanan dari pihak eksternal perusahaan sehingga perusahaan memiliki kewajiban untuk mengungkapkan tanggung jawab sosial perusahaan secara lebih luas (Dermawan dan Deitiana 2014).

Variabel financial leverage memiliki nilai signifikansi sebesar 0.392 dimana nilai tersebut lebih besar dari 0.05 sehingga $\mathrm{H}_{7}$ tidak diterima, artinya financial leverage tidak memiliki pengaruh terhadap pengungkapan tanggung jawab sosial perusahaan dan arahnya positif. Perusahaan dengan tingkat leverage yang tinggi biasanya mengungkapkan informasi pengungkapan CSR yang lebih banyak (Santioso dan Chandra, 2012). Hal ini dilakukan guna menghilangkan keraguan kreditor terhadap dipenuhinya hak-hak kreditor (Dewi dan Keni 2013). Namun, kreditor tidak terlalu memerhatikan seberapa luas pengungkapan CSR karena menurut kreditor yang penting adalah bagaimana kinerja perusahaan untuk melunasi kewajibannya (Sumilat dan Destriana 2017).

Variabel listing age memiliki nilai signifikansi sebesar 0.001 sehingga $\mathrm{H}_{8}$ diterima, artinya listing age memiliki pengaruh terhadap pengungkapan tanggung jawab sosial perusahaan. Umur perusahaan yang semakin bertambah berhubungan dengan perkembangan perusahaan yang mengarah pada kemajuan. Namun perusahaan yang mengalami penuaan harus mengurangi biaya berbagai efek pembelajaran yang ditempuh dan belajar dari perusahaan lainnya (Munsaidah et al. 2012). Selain itu, perusahaan yang sudah tua tidak membutuhkan legitimasi lagi karena perusahaan sudah dikenal masyarakat.

\section{PENUTUP}

Berdasarkan hasil penelitian ini, dapat disimpulkan bahwa board size, firm size, profitability dan listing age memiliki pengaruh terhadap pengungkapan tanggung jawab sosial perusahaan. Namun, variabel board independence, women on board, financial leverage, dan internationalization tidak memiliki pengaruh terhadap pengungkapan tanggung jawab sosial perusahaan. Penelitian ini memiliki beberapa keterbatasan yaitu (1) Sampel penelitian yang digunakan dalam penelitian ini hanya perusahaan manufaktur yang terdapat di Bursa Efek Indonesia periode 2015 hingga 2018. (2) Terdapat masalah heteroskedastisitas pada variabel board independence dan firm size serta masalah autokorelasi. (3) Terbatasnya penggunaan variabel independen yaitu board size, board independence, women on board, firm size, profitability, financial leverage, internationalization, dan listing age.

Rekomendasi yang dapat diberikan oleh penulis untuk penelitian selanjutnya adalah sebagai berikut (1) Penelitian selanjutnya tidak hanya terbatas pada perusahaan manufaktur saja, melainkan bisa menggunakan perusahaan jasa, keuangan, maupun non-keuangan. (2) Peneliti selanjutnya dapat menambahkan periode penelitian untuk mengatasi masalah heteroskedastisitas dan autokorelasi. (3) Penelitian selanjutnya dapat menambahkan variabel lain yang dapat mempengaruhi 
pengungkapan tanggung jawab sosial perusahaan seperti variabel kepemilikan manajerial (Jensen dan Meckling, 1976), variabel reputasi (Dyduch dan Krasodomska 2017), variabel kepemilikan institusional (Zulvina et al. 2017), variabel profil perusahaan
(Yuliana et al. 2008), variabel tipe auditor (Uyar et al. 2013), dan variabel pertumbuhan perusahaan (Munsaidah et al. 2016).

\section{REFERENCES:}

Adeyene, Yusuf Babatunde dan Maryam Ahmed. 2015. Corporate Social Responsibility and Company Performance. Journal of Business Studies Quarterly, 7(1), 151-166.

Alchian, Armen A., Harold Demzet. 1972. Production, Information Costs, and Economic Organization. The American Economic Review, 62(5), 777-795

Almilia, Luciana S., Nurul Hasanah Uswati Dewi dan Vidiana Hastutik Is Hartono. 2011. Faktor-Faktor yang Mempengaruhi Pengungkapan Tanggung Jawab Sosial Perusahaan Dan Dampaknya Dalam Kinerja Keuangan Dan Ukuran Perusahaan. Fokus Ekonomi, 10(1), 50-68.

Agustia, Dian. 2013. Pengaruh Struktur Kepemilikan dan Dewan Komisaris Terhadap Corporate Social Responsibility dan Reaksi Pasar. Jurnal Ekonomi dan Keuangan, 17(3), 376-390.

Anggraini, Reni Retno. 2006. Pengungkapan Informasi Sosial dan Faktor-Faktor Yang Mempengaruhi Pengungkapan Informasi Sosial dalam Laporan Keuangan Tahunan (Studi Empiris Pada PerusahaanPerusahaan yang Terdaftar Di Bursa Efek Jakarta). Simposium Nasional Akuntansi 9 Padang,1-21.

Badjuri, Achmad. 2011. Faktor-Faktor Fundamental Mekanisme Corporate Governance, Pengungkapan Corporate Social Responsibility (CSR) Perusahaan Manufaktur dan Sumber Daya Alam Di Indonesia. Dinamika Keuangan dan Perbankan, 3(1), 38-54.

Bangun, Nurainun., Christie Andhika, dan Henryanto Wijaya. 2016. Pengaruh Tipe Industri, Mekanisme Corporate Governance, dan Ukuran Perusahaan Terhadap Corporate Social Responsibility Disclosure. Jurnal Bisnis dan Akuntansi, 18(2), 123-130.

Bernardi, R.A dan Veronica. H.T. 2010. Woman Directors and Corporate Social Responsibility. Electronic Journal of Business Ethics and Organization Studies, 15(2), 15-21.

Budiman, Nita Andriyani. 2015. Faktor-Faktor yang Mempengaruhi Pengungkapan Tanggung Jawab Sosial Perusahaan. Prodi Akuntansi, Fakultas Ekonomi, UMB Yogyakarta, 1(1), 15-34.

Cheng, Megawati dan Yulius Yogi Christiawan. 2011. Pengaruh Pengungkapan Corporate Social Responsibility Terhadap Abnormal Return. Jurnal Akuntansi dan Keuangan, 13(1), 24-36.

Chintya, Dwi Putri. 2013. Pengaruh Corporate Governance dan Karakteristik Perusahaan Terhadap Pengungkapan Tanggung Jawab Sosial Perusahaan di dalam Sustainability Report: Studi Empiris Perusahaan yang Terdaftar di BEl. Jurnal Universitas Negri Padang.

Coller, P. dan A. Gregory. 1999. Audit Committee Activity and Agency Costs. Journal Accounting and Public Policy. 18(4-5), 311-332.

Dermawan, Decky dan Tita Deitiana. 2014. Faktor-Faktor yang Mempengaruhi Pengungkapan Corporate Social Responsibility. Jurnal Bisnis dan Akuntansi, 16(2), 158-165.

Dewi, Sofia Prima dan Keni. 2013. Pengaruh Umur Perusahaan, Profitabilitas, Ukuran Perusahaan, dan Leverage Terhadap Pengungkapan Tanggung Jawab Sosial Perusahaan. Jurnal Bisnis dan Akuntansi, 15(1), 1-12.

Dyduch, Justyna dan Joanna Krasodomska. 2017. Determinants of Corporate Social Responsibility Disclosure: An Empirical Study of Polish Listed Companies. Sustainability, 9(11),1-24.

Fontaine, Michael. 2013. Corporate Social Responsibility and Sustainability:The New Bottom Line?. International Journal of Business and Social Science, 4(4), 110-119.

Gill, Amiram. 2008. Corporate Governance as a Social Responsibility: A Research Agenda. Berkeley Journal of International Law, 2(2), 452-478. 
Hidayati, Naila Nuur dan Sri Murni. 2009. Pengaruh Pengungkapan Corporate Social Responsibility Disclosure Terhadap Earningss Respone Coefficient Pada Perusahaan High Profile. Jurnal Bisnis dan Akuntansi, 11(1), 1-18.

Hyun, Eunjung., Daegyu Yang., Hojin Jung., dan Kihoon Hong. 2016. Women on Boards and Corporate Social Responsibility. Sustainability, 8(300), 1-26.

Isa, Muhammad Aminu dan Sabo Muhammad. 2015. The Impact of Board Characteristics on Corporate Social Responsibility Disclosure: Evidence from Nigerian Food Product Firms. International Journal of Management Science and Business Administration, 1(12), 34-45.

Jensen, Michael dan William Meckling. 1976. Theory of the Firm: Managerial Behavior, Agency Costs and Ownership Structure. Journal of Financial Economics, 3(4), 305-360.

Japoetra, D.B. \& Susanto, Y.K. 2020. Pengungkapan Tanggung Jawab Sosial Perusahaan Manufaktur: Studi Empiris Tata Kelola. MEDIA BISNIS, 12(1), 1-8.

Jo, Hoje dan Maretno A. Harjoto. 2011. Corporate Governance and Firm Value: The Impact of Corporate Social Responsibility. Journal of Business Ethics, 103(3), 351-383.

Lindawati, Ang Swat Lin dan Marsella Eka Puspita. 2015. Corporate Social Responsibility: Implikasi Stakeholder dan Legitimacy Gap Dalam Peningkatan Kinerja Perusahaan. Jurnal Akuntansi Multiparadigma. 6(1), 1174.

McWilliams, A. Dan D. Siegel, 2001. Corporate Social Responsibility: A Theory of Firm Perspective. Academy of Management Review, 26(1), 117-127.

Munsaidah, Siti., Rita Andini, dan Agus Supriyanto. 2016. Analisis Pengaruh Firm Size, Age, Profitabilitas, Leverage, dan Growth Perusahaan terhadap Corporate Social Responsibility (CSR) Pada Perusahaan Property dan Real Estate yang Terdaftar di Bursa Efek Indonesia pada Tahun 2010-2014. Journal of Accounting, 2(2).

Murwaningsari, Etty. 2009. Hubungan Corporate Governance, Corporate Social Responsibilities dan Corporate Financial Performance dalam Satu Continuum. Jurnal Akuntansi dan Keuangan, 11(1), 30-41.

Novita, Bunga Asri dan Sofie. 2015. Pengaruh Struktur Modal dan Likuiditas Terhadap Profitabilitas. E-Journal Akuntansi Trisakti, 2(1), 13-27.

Nugrahanti, Yeterina Widi. 2013. Karakteristik Perusahaan Terhadap Pengungkapan Corporate Social Responsibility (CSR) dan Dampaknya Terhadap Kinerja Keuangan. Jurnal Manajemen dan Bisnis, 12(1), 128-142.

Nur, Marzully dan Denies Priantinah. 2012. Analisis Faktor-Faktor Yang Mempengaruhi Pengungkapan Corporate Social Responsibility di Indonesia (Studi Empiris Pada Perusahaan Berkategori High Profile Yang Listing di Bursa Efek Indonesia). Jurnal Nominal, 1(1), 22-34.

Pajaria, Yusiresita., Meutia Intan., dan Marlina Widiyanti. 2016. Pengaruh Diveritas Dewan Direksi dan Komisaris, Ukuran Perusahaan, dan Profitabilitas Terhadap Pengungkapan Corporate Social Responsibility Perusahaan Sektor Manufaktur yang Terdaftar di Bursa Efek Indonesia. Jurnal Penelitian dan Pengembangan Akuntansi, 10(2), 177-200.

Putra, Eka Wirmie, Yuliusman dan Dedy Setiawan. 2011. Pengaruh Size, Profitabilitas, Leverage, Kepemilikan Dalam Negri dan Kepemilikan Asing Terhadap Pengungkapan Tanggung Jawab Sosial Perusahaan. Jurnal Penelitian Universitas Jambi Seri Humaniora, 13(2), 37-48.

Prihadi, Toto. 2008. Deteksi Cepat Kondisi Keuangan: 7 Analisis Rasio Keuangan. Pengembangan Eksekutif.

Rasyidah, Resa. 2013. Perbandingan Corporate Governance Dengan Sistem One-Tier Board Di Inggris dan AS Terkait Efektivitas Pencegahan Terjadinya Fraud dalam Korporasi. Global Policy, 1(1), 11-18.

Rohmah, Dita. 2015. Faktor-Faktor yang Mempengaruhi Pengungkapan Corporate Social Responsibility didalam Laporan Sustainability. Jurnal Bisnis dan Manajemen, 5(2), 243-262.

Rokhlinasari, Sri. 2015. Teori-Teori dalam Pengungkapan Informasi Corporate Social Responsibility Perbankan. Jurnal Ekonomi dan Perbankan Syari'ah, 2(15), 1-11.

Rudyanto, Astrid. 2019. Mimetic Isomorphism as a Reason for Preparing Sustainability Report. Jurnal Akuntansi Multiparadigma, 10(3). 
Santioso, Linda dan Erline Chandra. 2012. Pengaruh Profitabilitas, Ukuran Perusahaan, Leverage, Umur Perusahaan, Dan Dewan Komisaris Independen Dalam Pengungkapan Corporate Social Responsibility. Jurnal Bisnis dan Akuntansi, 14(1), 17-30.

Sembiring, Eddy Rismanda. 2005. Karakteristik Perusahaan dan Pengungkapan Tanggung Jawab Sosial: Study Empiris pada Perusahaan yang Tercatat di Bursa Efek Jakarta. Prosiding Simposium Nasional Akuntansi VIII. 15 - 16 Desember, di Solo, Indonesia.

Sufian, Mohammad Abu. 2012. Corporate Social Responsibility Disclosure in Bangladesh. Global Journal of Management and Business Research, 12(14), 148-155.

Sufian, Mohammad Abu dan Muslima Zahan. 2013. Ownership Structure and Corporate Social Responsibility in Bangladesh. International Journal of Economic and Financial Issues, 3(4), 901-909.

Sumilat, Hillary dan Nicken Destriana. 2017. Faktor-Faktor yang Mempengaruhi Pengungkapan Corporate Social Responsibility Disclosure. Jurnal Bisnis dan Akuntansi, 19(1a), 129-140.

Sunaryo. 2013. Pengaruh Company Size, Company Ages, Profitability, Dan Leverage Terhadap CSR Disclosure Pada Kelompok Perusahaan Properti dan Real Esatate Yang Terdaftar Di BEl. Journal The Winners, 14(1), 61-69.

Susanto, Y.K. \& Joshua, D. 2018. Pengaruh tata kelola perusahaan dan Karakteristik Perusahaan Terhadap Pengungkapan Tanggung Jawab Sosial Perusahaan. EKUITAS (Jurnal Ekonomi dan Keuangan), 2(4), 572-590.

Susanto, Y.K. 2019. Corporate Social Responsibility Disclosure: Corporate Governance and Profitability. South East Asia Journal of Contemporary Business, Economics and Law, 20(1), 39-44.Untari, Lisna. 2010. Effect on Company Characteristics Corporate Social Responsibility Disclosure in Corporate Annual Report of Consumption Listed in Indonesia Stock Exchange. Gudadarma University.

Uyar, Ali, Merve Kilic, dan Nizamettin Bayyurt. 2013. Association Between Firm Characteristics And Corporate Voluntary Disclosure: Evidence From Turkish Listed Companies. Intangible Capital, 9(4), 1080-1112.

Wagiu, Frily Ansyelia dan Peggy A. Mekel. 2014. The Effet of Firm Size, Profitability, Leverage, and Board Size on Disclosure of Corporate Social Responsibility In Company's Annual Reports. Jurnal Ekonomi Manajemen Bisnis dan Akuntansi (EMBA), 2(3), 1540-1549.

Yuliana, Rita, Bambang Purnomosidhi, Eko Ganis Sukoharsono. 2008. Pengaruh Karakteristik Perusahaan Terhadap Pengungkapan Corporate Social Responsibility (CSR) dan Dampaknya Terhadap Reaksi Investor. Jurnal Akuntansi dan Keuangan Indonesia, 5(2), 245-276. 